\title{
Atmospheric mercury pollution: the current methodological framework outlined by environmental legislation
}

\author{
Francesco Ciani ${ }^{1} \cdot$ Valentina Rimondi $^{1,2}$ (D) Pilario Costagliola ${ }^{1,2}$ \\ Received: 15 January 2021 / Accepted: 6 May 2021 / Published online: 15 May 2021 \\ (C) The Author(s) 2021
}

\begin{abstract}
Mercury is a toxic pollutant that exists in the atmosphere in several forms, operationally identified according to their chemical and physical characteristics. The problem of atmospheric mercury pollution has recently received increasing attention, as evidenced by the numerous European regulations issued in the last years. The normative question is closely related to the methodological one, as the quantification of the mercury species is strictly linked to the sampling and analysis methods. Due to their different bioavailability, airborne mercury forms detection is fundamental both in outdoor and indoor (i.e., workplace) environments. This paper presents an overview of European legislation on atmospheric mercury pollution, with particular attention to the Italian legislation. Starting from the regulatory protocols, the methodological framework for mercury quantification was reviewed, underlining the limits and the problems of the different methodologies and providing new guidance for the analysis. Regulatory and methodological updates have led to great specificity in mercury quantification, which is distinguished for the outdoor and indoor environments. For workplace environments, all mercury species (i.e., gaseous and particulate mercury) are required to be quantified by the Italian legislation; on the contrary, only gaseous compounds are monitored in outdoor conditions. It hence appears of primary importance that the monitoring operator chooses the sampling and analytical method for mercury sampling and analysis that correctly adheres to the normative regulations. Detailed norms describe how to carry on the monitoring in both outdoor and indoor conditions, preventing the operator's arbitrariness, which otherwise can lead to airborne mercury underestimation/overestimation.
\end{abstract}

Keywords Airborne mercury $\cdot$ Air quality $\cdot$ Standard methodologies $\cdot$ Environmental legislation

\section{Introduction}

Mercury (Hg), one of the most toxic substance naturally occurring on the Earth's crust, exists in the environment in several chemical and physical forms, characterized by specific transport properties and environmental effects (Schroeder and Munthe 1998).

In the atmosphere, $\mathrm{Hg}$ occurs in three forms: gaseous elemental (GEM), reactive gaseous or oxidized (RGM), and particulate bound (PBM). The sum of GEM and RGM is indicated as total gaseous $\mathrm{Hg}$ (TGM) (Fu et al. 2012). The distinction among these species is mainly operational, since TGM is

Valentina Rimondi

valentina.rimondi@unifi.it

1 Dipartimento di Scienze della Terra, Università di Firenze, Via G. La Pira 450121 Firenze Italy

2 CNR-IGG, Via G. La Pira 450121 Firenze Italy defined as the fraction of $\mathrm{Hg}$ that passes through a filter with pores of $0.45 \mu \mathrm{m}$ (Munthe et al. 2001).

GEM, the predominant form of TGM in the atmosphere (> 95\%; i.e., Fitzgerald et al. 2005), is characterized by high stability, bioavailability, and volatility; among the three atmospheric forms, GEM is the only one that has been experimentally identified with spectroscopic methods (Edner et al. 1989).

RGM definition is troublesome as it includes a large variety of gaseous inorganic (i.e., $\mathrm{HgCl}_{2}$ and $\mathrm{HgO}$ ) and organic compounds with sufficiently high vapor pressure to exist as gasphase (Munthe et al. 2001). It is operationally defined as the $\mathrm{Hg}$ fraction that can be sampled on a potassium chloridecoated denuder (Landis et al. 2002).

PBM consists of all airborne particulate containing $\mathrm{Hg}$, including both stable condensed and gaseous forms adsorbed on atmospheric particulate matter (PM); it is operationally sampled by pulling air through a glass fiber or a quartz filter (Lynam and Keeler 2002), which is later acid-digested and analyzed for Hg. PBM usually includes all those particles with 
diameter $<2.5 \mu \mathrm{m}$, even if its characterization only depends on the pore size of the filter used for its collection (Bank 2012).

Detecting and quantifying the different $\mathrm{Hg}$ airborne forms is essential because of their different bioavailability. GEM is rapidly and almost completely absorbed in the lungs (ca. $80 \%$ ); inhalation is then the main route of exposure, while $\mathrm{Hg}^{0}$ from ingestion is poorly adsorbed in the gastrointestinal tract $(<0.01 \%)$. Thanks to its high affinity with the membrane lipids, GEM is highly diffusible within the body; it can cross the blood-brain barrier and accumulate in the central nervous system before being oxidized (Park and Zheng 2012).

RGM compounds enter in the human body mainly by ingestion, since the inhaled fraction is only partially absorbed (less than 50\% in animals, according to Morrow et al. 1964). Inorganic $\mathrm{Hg}$ forms are partially absorbed in the gastrointestinal tract (ca. 7-15\% of the total ingested), and then excreted in the urine and feces; the highest concentration is found in the kidney since the proximal tubule is the main site of absorption and accumulation of $\mathrm{Hg}^{2+}$ (Park and Zheng 2012). Organic $\mathrm{Hg}$ forms are quickly dissolved in fat and almost completely absorbed in the gastrointestinal tract; after gastric-acid digestion, they easily combine with the hemoglobin of red blood cells and accumulate in the central nervous system (Hong et al. 2012).

The clinical effects resulting from a chronical exposure to high $\mathrm{Hg}$ concentrations are numerous and include complications in the respiratory (bronchitis, interstitial pneumonia, respiratory failure), circulatory (tachycardia, hypertension), gastrointestinal (abdominal pain, nausea, diarrhea, ulcers), and renal (mainly nephritis) systems; these symptoms are often combined with central nervous system disorders (cognitive, sensory, motor alterations) (Fisher and World Health Organization 2003).

The exposure to the different airborne $\mathrm{Hg}$ species mainly results by anthropogenic activities, in particular by industrial facilities like coal-fired power stations, metal extraction, waste incineration or chemical industries (Pandey et al. 2011). Atmospheric $\mathrm{Hg}$ pollution can also be due to daily household activities, like cooking or smoking, or from the large variety of devices containing $\mathrm{Hg}$, as well as the possible proximity to source point emission (Kim et al. 2016). Nevertheless, acute exposures to $\mathrm{Hg}$ compounds are mainly related to occupational monitoring or accidental contacts. Exposure to $18-30 \mathrm{mg} /$ $\mathrm{m}^{3}$ for $3-5 \mathrm{~h}$ and $43 \mathrm{mg} / \mathrm{m}^{3}$ for $2-3 \mathrm{~h}$ to $\mathrm{Hg}$ vapor killed some people (mostly industrial workers or during gold ore processing), while exposure to $13-16 \mathrm{mg} / \mathrm{m}^{3}$ for several hours caused respiratory syndromes (AIHA 2002 and references therein). World Health Organization (WHO 2003) suggested that a long-term exposure to $\mathrm{Hg}$ vapor concentrations more than $0.02 \mathrm{mg} / \mathrm{m}^{3}$ may cause slight intoxication symptoms, while concentrations between 0.4 and $2 \mathrm{mg} / \mathrm{m}^{3}$ is expected to cause chronic $\mathrm{Hg}$ poisoning (AIHA 2002 and references therein).
The increasing engagement in the worldwide $\mathrm{Hg}$ pollution reduction has been realized with the subscription in 2013 of the Minamata Convention, named as the Japanese city where the first large-scale incident of methyl- $\mathrm{Hg}$ poisoning took place. The subscription of the convention from all the EU countries, including Italy, has the objective of protecting health and the environment from anthropogenic $\mathrm{Hg}$ emissions. Although the convention was only ratified in 2017, the actions for a control of $\mathrm{Hg}$ emissions and for the protection of the citizens' health had started several years earlier. These actions are carried out through the drafting of a large number of protocols for detecting $\mathrm{Hg}$ in several environments (i.e., outdoor and workplace), including the $\mathrm{Hg}$ speciation (the different airborne $\mathrm{Hg}$ forms). The normative issue is closely linked to the methodological one and the definition of the Hg species studied strictly depend on the sampling method and/or instrument employed in the monitoring campaigns. Quantifying $\mathrm{Hg}$ speciation is especially crucial in those contexts, both in outdoor and workplaces environments (i.e., Obrist et al. 2009; Liu et al. 2009; Pyta et al. 2009), where GEM is not the unique $\mathrm{Hg}$ species, but especially PBM is significant.

As subscriber of the Minamata convention, a compulsory goal of Italy is to monitor $\mathrm{Hg}$ emission sources. Adherence of the normative (i.e., species of $\mathrm{Hg}$ required to be monitored) with the methods of analysis is an obviously pre-requisite for obtaining reliable and confident measurements.

In the present paper, we review the European regulations regarding the analytical methods for $\mathrm{Hg}$ analysis in outdoor and indoor (i.e., workplace) environments, with particular attention to those transposed by Italian legislation. Additionally, we elucidate the different legislative protocols and, in particular, the various methodological practices that should be followed depending on the $\mathrm{Hg}$ species to be quantified.

\section{International reference values for $\mathbf{H g}$}

The reference values for chemical agents reported in the literature are mainly referred to occupational exposure limits (OELs), defined by the Italian legislation (Legislative Decree n. 81/2008, Gazzetta Ufficiale n. 218 2012) as "the time-weighted average concentration limit of a chemical agent in the air within the breathing zone of a worker in relation to a specific reference period". These values are established by several international organizations that use different terminology for OELs. The American Conference of Governmental Industrial Hygienists (ACGIH®) refers to "Threshold Limit Value" (TLV®), specifying (i) a time-weighted average limit (TWAs), i.e., the 8-h weighted average exposure concentration limit to which it is believed that a worker may be repeatedly exposed, and (ii) a short-term exposure limit (STELs), i.e., a 15-min time-weighted average exposure that should not be exceeded at any time during a workday. Other 
organizations, like the American government Agency for Toxic Substances Disease Registry (ATSDR), sets a minimal risk level (MRL), i.e., an estimate of the daily human exposure to a hazardous substance which is not likely to cause an appreciable risk of non-cancerous adverse effects (ATSDR 1999). The reference values in the USA are established by the Occupational Safety and Health Administration (OSHA) that refers to permissible exposure limits (PELs) as legal limits enforceable in workplace. They refer to 8-h time-weighted averages (i.e., TWA); however also ceiling limits, i.e., concentrations that must not be exceeded at any time, have been established (OSHA 1998). TWAs are instead reported by the American National Institute for Occupational Safety and Health (NIOSH) as recommended exposure limits (RELs), even if they are based on a 10-h workday during a 40-h workweek; RELs are basically similar to the OSHA PELs, except that they are not legally recognized limits, but suggested values to modify/update the PELs. NIOSH also sets the immediately dangerous to life or health air concentration values (IDLHs) to define an airborne exposure "likely to cause death or immediate or delayed permanent adverse health effects or prevent escape from such an environment" (NIOSH 1994a, b).

The reference values for airborne $\mathrm{Hg}$ compounds are numerous and different according to the $\mathrm{Hg}$ species monitored (Fig. 1). The ACGIH formulates a TLV of $0.025 \mathrm{mg} / \mathrm{m}^{3}$ for GEM and inorganic Hg compounds (ACGIH® 2020). ATSDR sets a MRL of $0.0002 \mathrm{mg} / \mathrm{m}^{3}$ to avoid chronic exposure to $\mathrm{Hg}$, and a REL of $0.001 \mathrm{mg} / \mathrm{m}^{3}$ in private home (ATSDR 1999); both values refer to $\mathrm{Hg}$ inhalation, but the $\mathrm{Hg}$ form is not specified.

Regarding the occupational exposure level for workers, the OSHA PEL and the NIOSH REL are both $0.05 \mathrm{mg} / \mathrm{m}^{3}$, while the ceiling values are both at $0.1 \mathrm{mg} / \mathrm{m}^{3}$; NIOSH sets also a
IDLH of $10 \mathrm{mg} / \mathrm{m}^{3}$ (OSHA 1991; NIOSH 1994a, b). The above reference values refer to inorganic $\mathrm{Hg}$ and its compounds, while for organo (alkyl) Hg compounds, ACGIH (TLV), OSHA (PEL), and NIOSH (REL) are all set at 0.01 mg $/ \mathrm{m}^{3}$ (NIOSH 1981; OSHA 1998; ACGIH® 2020) (Fig. 1).

\section{The regulatory framework for airborne $\mathrm{Hg}$ : outdoor and indoor environments}

\section{The outdoor environment}

The outdoor pollution due to atmospheric $\mathrm{Hg}$ compounds was deal for the first time in the EC directive 2004/107/EC 2004 of the European Parliament and of the Council of 15 December "relating to arsenic, cadmium, mercury, nickel and polycyclic aromatic hydrocarbons in ambient air" (EC directive 2004/ 107/EC 2004). The analyte reported by this Directive is the "total gaseous mercury" defined as "elemental mercury vapor and reactive gaseous mercury, i.e., water-soluble mercury species with sufficiently high vapor pressure to exist in the gas phase"; as reported above, this wording coincides with the operative definition of TGM (i.e., the sum of GEM and RGM).

The Directive 2004/107/EC was later revised and implemented by the EC Directive 2008/50/EC (EC directive 2008/ 50/EC 2008) of the European Parliament and the Council of European Union of 21 May 2008 on "ambient air quality and cleaner air for Europe"; however, no particular differences were introduced for $\mathrm{Hg}$ with respect to the previous Directive (2004/107/EC).
Fig. 1 Reference values for airborne $\mathrm{Hg}$ compounds. A ATSDR (MRL) to avoid chronic exposure. B ATSDR (REL) for private home. C ACGIH (TLV), OSHA (PEL), and NIOSH (REL) for organic Hg compounds. D Exposure limit value for inorganic Hg compounds in workplace air reported by Italian legislation (Legislative Decree n. 81/2008), calculated as time-weighted average (8-h per day, 5 days per week). E ACGIH (TLV) for GEM and inorganic Hg compounds. F OSHA (PEL) and NIOSH (REL) for inorganic $\mathrm{Hg}$ compounds. G OSHA and NIOSH ceiling value for inorganic $\mathrm{Hg}$ compounds. H NIOSH (IDLH) for inorganic $\mathrm{Hg}$ compounds

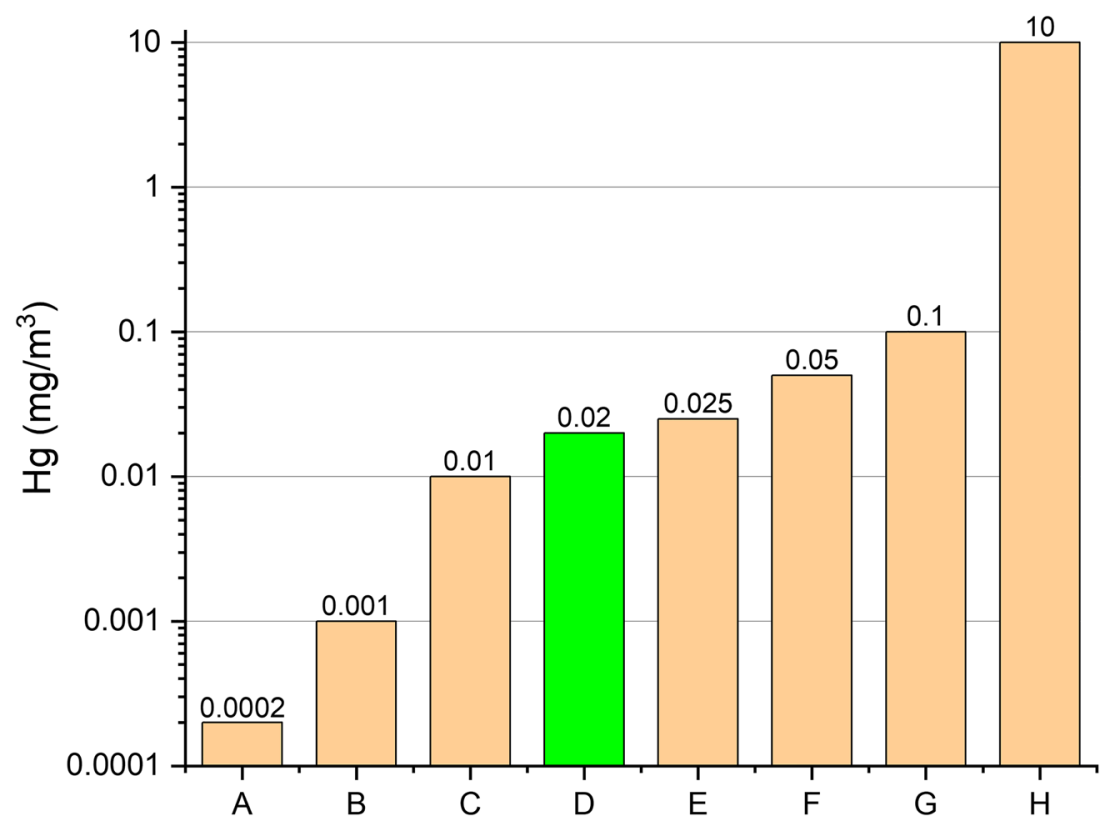


The two EC directive 2004/107/EC 2004 and 2008/50/EC 2008) are both implemented by the Italian legislation, respectively with the Legislative Decree n. 152/2007 (Gazzetta Ufficiale n. 213 2007) and the Legislative Decree n. 155/ 2010 (Gazzetta Ufficiale n. 216 2010).

Substantial changes, especially from the methodological point of view, have been introduced by the EN 15852:2010 standard ("Ambient air quality-Standard method for the determination of total gaseous mercury", UNI EN 15852:2010), implemented by the Italian legislation with the Legislative Decree n. 250/2012 (Gazzetta Ufficiale n. 23 2013). As in the previous EC Directives, the definition of the analyte under investigation (total gaseous $\mathrm{Hg}$ ) coincides with the operational definition of TGM.

\section{The indoor environment}

Despite increasing public health concern related to the indoor air quality due to the amount of time that people spend indoor during the day, specific reference directives are lacking in the European legislation. The subject is rather regulated by prelegislative initiatives, i.e., specific documents elaborated by national or European working groups (Kurt-Karakus 2012; Settimo et al. 2020). In these initiatives, indoor pollution monitoring often coincides with workplace air quality.

The Italian law on health and safety at work (Legislative Decree n. 81, GU Gazzetta Ufficiale n. 101 (2008) reports the exposure limit value of $0.02 \mathrm{mg} / \mathrm{m}^{3}$ as time-weighted average (8-h per day, 5 days per week), for "mercury and divalent inorganic compounds of mercury, including mercury oxide and mercury chloride (measured as mercury)" (translated from the Gazzetta Ufficiale n. 218 2012). Different from outdoor environment, where only TGM should be monitored, all total inorganic $\mathrm{Hg}$ compounds should be monitored in indoor conditions; PBM is then included in this definition.

As regards the guidelines for the sampling and analysis, no specific reference is made to $\mathrm{Hg}$ in the Legislative Decree $\mathrm{n}$. 81/2008. The art. 225 ("Specific measures of protection and prevention") states the obligation for the employer to "measure the pollutants that may present a risk to workers' health, using standardized methods reported in an indicative list in the Annex XLI". The list is made up of nine European Standards methods implemented by the Italian legislation (specifically, UNI EN 481, 482, 689, 838, 1076, 1231, 1232, 1540, 12919) that deal with the sampling methods and operational requirements for the assessment of the pollutants in the workplace atmosphere. Among these, there is no specific methodology to be applied for atmospheric $\mathrm{Hg}$ pollution on workplace. The only reference, albeit indirect, can be obtained from what is reported in the UNI EN 482 ("Workplace exposure-General requirements for the performance of procedures for the measurement of chemical agents") where the paragraph "Chemical agents with low limit values" suggests the possibility to consider the protocols reported in the GESTIS Analytical Methods database (GESTIS 2015) on hazardous substances by IFA (Information System on Hazardous Substances of the German Social Accident Insurance), an online information system whose contents are continuously updated after the publication of new regulations. Among those specific for $\mathrm{Hg}$ (Table 1), a particular importance is attributed to the ISO 17733:2015 ("Workplace air-Determination of mercury and inorganic mercury compounds - Method by cold-vapor atomic absorption spectrometry or atomic fluorescence spectrometry"). The protocol reported by this international standard does not refer to a specific $\mathrm{Hg}$ form, but indicates that "the results may be used for the assessment of workplace exposure to mercury vapor, inorganic mercury compounds or total inorganic mercury" (see details on the method in the following paragraphs).

\section{Regulatory protocols for $\mathrm{Hg}$ analysis}

\section{The outdoor environment}

The first community regulations that addressed the problem of atmospheric $\mathrm{Hg}$ pollution did not report a precise method for sampling the different $\mathrm{Hg}$ compounds. Indeed, the EC directive 2004/107/EC 2004 only states that the reference method for measuring TGM will be "an automated method based on atomic absorption or atomic fluorescence spectrometry" and that "in the absence of a standardized CEN (European Committee for Standardization) method, the Member States are allowed to use international standard methods or standard ISO (International Organization for Standardization) methods." In this regard, the Italian legislation states that this reference method is the one developed by the CNR (National Research Council), specifying that this may be replaced if a CEN method is issued.

The method reported by the Italian legislation (Legislative Decree n. 152/2007; Legislative Decree n. 155/2010) is based on the process of amalgamation of airborne $\mathrm{Hg}$ compounds with gold, following by the quantification through cold vapor atomic fluorescence spectroscopy (CVAFS). The preconcentration of $\mathrm{Hg}$ forms on gold surfaces is necessary because the sensitivity of the CVAFS analysis is not so high for a real-time measurement (Gustin et al. 2015). The sampling should be carried out using quartz tube traps containing $0.7 \mathrm{~g}$ of gold and quartz granules or, alternatively, small quartz granules covered with a gold film embedded by quartz wool. The protocol reports the use of two traps in series, a sampling pump, and a glass fiber filter placed upstream the first trap to exclude PBM (the filter is indeed not digested, according to the protocol); the pore size of the filter is not specified. The atmospheric $\mathrm{Hg}$ is adsorbed by the gold/quartz granules of the "sample trap" (i.e., the first trap along the sampling line); then $\mathrm{Hg}$ is thermally desorbed $\left(500{ }^{\circ} \mathrm{C}\right)$ from the sample trap and 
Table 1 Sampling and analysis methods for $\mathrm{Hg}$ as reported in the GESTIS database

\begin{tabular}{|c|c|c|c|c|c|c|c|}
\hline Source method & Language & $\begin{array}{l}\text { Year of } \\
\text { publication }\end{array}$ & Principle of the method & $\begin{array}{l}\text { Flow rate/ } \\
\text { Recommended } \\
\text { air volume }\end{array}$ & $\begin{array}{l}\mathrm{LOQ} / \\
\text { Validated } \\
\text { working } \\
\text { range }\end{array}$ & $\begin{array}{l}\text { Indicative } \\
\text { rating }{ }^{A}\end{array}$ & Remarks \\
\hline $\begin{array}{l}\text { ISO } 17733- \\
\text { Determination of } \\
\text { mercury and in- } \\
\text { organic mercury } \\
\text { compounds }\end{array}$ & $\begin{array}{l}\text { English } \\
\text { France }\end{array}$ & 2004 & $\begin{array}{l}\text { Pumped sampling: } \\
\text { Mercury vapor trapped using a } \\
\text { sorbent tube containing } \\
\text { Hydrar (with a QF prefilter } \\
\text { for particulate mercury, if } \\
\text { present). } \\
\text { Diffusive sampling: } \\
\text { Mercury vapor sampled using } \\
\text { a badge containing Hydrar. } \\
\text { Dissolution with } \mathrm{HNO}_{3} \text { and } \\
\mathrm{HCl} \text { at room temperature. } \\
\text { Analysis by } \mathrm{CVAAS} \text { after } \\
\text { reduction using } \mathrm{SnCl}_{2} \text {. }\end{array}$ & $\begin{array}{l}\text { Pumped } \\
\quad \text { sampling: } \\
200 \mathrm{ml} / \mathrm{min} \\
12-961 \\
\text { Diffusive } \\
\quad \text { sampling: } \\
20 \mathrm{ml} / \mathrm{min} \\
>721\end{array}$ & $\begin{array}{l}\text { LOQ: } \\
\text { Pumped } \\
\quad \text { sampling: } \\
0.003 \mathrm{mg} / \mathrm{m}^{3} \\
121 \\
\text { Diffusive } \\
\quad \text { sampling: } \\
0.006 \mathrm{mg} / \mathrm{m}^{3} \\
721\end{array}$ & A & \\
\hline $\begin{array}{l}\text { MDHS } 16 / 2- \\
\text { Mercury and its } \\
\text { inorganic } \\
\text { divalent } \\
\text { compounds in air }\end{array}$ & English & 2002 & $\begin{array}{l}\text { Pumped sampling: } \\
\text { Mercury vapor trapped using a } \\
\text { sorbent tube containing } \\
\text { Hydrar (with a QF prefilter } \\
\text { for particulate mercury, if } \\
\text { present). } \\
\text { Diffusive sampling: } \\
\text { Mercury vapor sampled using } \\
\text { a badge containing Hydrar. } \\
\text { Dissolution with } \mathrm{HNO}_{3} \text { and } \\
\mathrm{HCl} \text { at room temperature. } \\
\text { Analysis by } \mathrm{CVAAS} \text { after } \\
\text { reduction using } \mathrm{SnCl}_{2} \text {. }\end{array}$ & $\begin{array}{l}\text { Pumped } \\
\quad \text { sampling: } \\
200 \mathrm{ml} / \mathrm{min} \\
12-961 \\
\text { Diffusive } \\
\quad \text { sampling: } \\
20 \mathrm{ml} / \mathrm{min} \\
>721\end{array}$ & $\begin{array}{l}\text { LOQ: } \\
\text { Pumped } \\
\quad \text { sampling: } \\
0.003 \mathrm{mg} / \mathrm{m}^{3} \\
121 \\
\text { Diffusive } \\
\quad \text { sampling: } \\
0.006 \mathrm{mg} / \mathrm{m}^{3} \\
721\end{array}$ & A & $\begin{array}{l}\text { Identical to methods } \\
\text { described in ISO } \\
17733\end{array}$ \\
\hline $\begin{array}{l}\text { MetroPol 024- } \\
\text { Mercure sur } \\
\text { tubes de charbon } \\
\text { actif }\end{array}$ & French & 2000 & $\begin{array}{l}\text { Mercury vapor trapped using a } \\
\text { sorbent tube containing } \\
\text { activated charcoal. } \\
\text { Thermal desorption at } 500{ }^{\circ} \mathrm{C} \\
\text { under N2 into acidic } \\
\text { KMnO4 solution; then } \\
\text { treatment of an aliquot by } \\
\text { addition of saturated } \\
\mathrm{KMnO} 4 \text { solution, } 1+1 \\
\mathrm{HNO} 3,1+1 \mathrm{H} 2 \mathrm{SO} 415 \mathrm{~g} / \mathrm{L} \\
\mathrm{NH} 2 \mathrm{OH} . \mathrm{HCl} \text {. } \\
\text { Analysis by CVAAS after } \\
\text { reduction using } \mathrm{SnCl} 2 .\end{array}$ & $\begin{array}{l}11 / \min \\
15-2401\end{array}$ & $\begin{array}{l}\text { LOQ: } \\
0.014 \mathrm{mg} / \mathrm{m}^{3} \\
151 \\
0.0008 \\
\quad \mathrm{mg} / \mathrm{m}^{3} \\
2401\end{array}$ & B & $\begin{array}{l}\text { No performance data } \\
\text { published in the } \\
\text { method }\end{array}$ \\
\hline $\begin{array}{l}\text { MetroPol 079- } \\
\text { Mercure sur } \\
\text { tubes Hydrar }{ }^{\circledR}\end{array}$ & French & 2003 & $\begin{array}{l}\text { Mercury vapor trapped using a } \\
\text { sorbent tube containing } \\
\text { hopcalite (with a } \mathrm{QF} \\
\text { prefilter for particulate } \\
\text { mercury, if present). } \\
\text { Ultrasonic dissolution with } \\
\mathrm{HNO} 3 \text { and } \mathrm{HCl} \text { at room } \\
\text { temperature. } \\
\text { Analysis by } \mathrm{CVAAS} \text { after } \\
\text { reduction using } \mathrm{SnCl} 2 \text {. }\end{array}$ & $\begin{array}{l}500 \mathrm{mg} \text { tubes: } \\
1-21 / \mathrm{min} \\
60-4801 \\
200 \mathrm{mg} \text { tubes: } \\
0.15-0.25 \mathrm{l} / \mathrm{min} \\
3-1001\end{array}$ & $\begin{array}{l}\text { LOQ: } \\
\text { Refer to } \\
\text { ISO } 17733\end{array}$ & B & $\begin{array}{l}\text { No performance data } \\
\text { published in the } \\
\text { method. } \\
\text { Similar to ISO } 17733\end{array}$ \\
\hline $\begin{array}{l}\text { BIA } 8530- \\
\text { Quecksilber }\end{array}$ & German & 2004 & $\begin{array}{l}\text { Mercury vapor trapped using a } \\
\text { sorbent tube containing two } \\
\text { sections of hopcalite } \\
\text { separated by a QF filter. } \\
\text { Dissolution with } \mathrm{HNO} 3 \text { and } \\
\mathrm{HCl} \text { at } 80^{\circ} \mathrm{C}(1 \text { st sorbent } \\
\text { section and QF filter treated } \\
\text { together; } 2 \text { nd back-up sor- } \\
\text { bent section treated sepa- } \\
\text { rately). }\end{array}$ & $\begin{array}{l}601 / h \\
1201\end{array}$ & $\begin{array}{l}\text { LOQ: } \\
0.004 \mathrm{mg} / \mathrm{m}^{3} \\
1201\end{array}$ & B & $\begin{array}{l}\text { Brief method } \\
\quad \text { description. } \\
\text { Similar to } \\
\text { ISO } 17733\end{array}$ \\
\hline
\end{tabular}


Table 1 (continued)

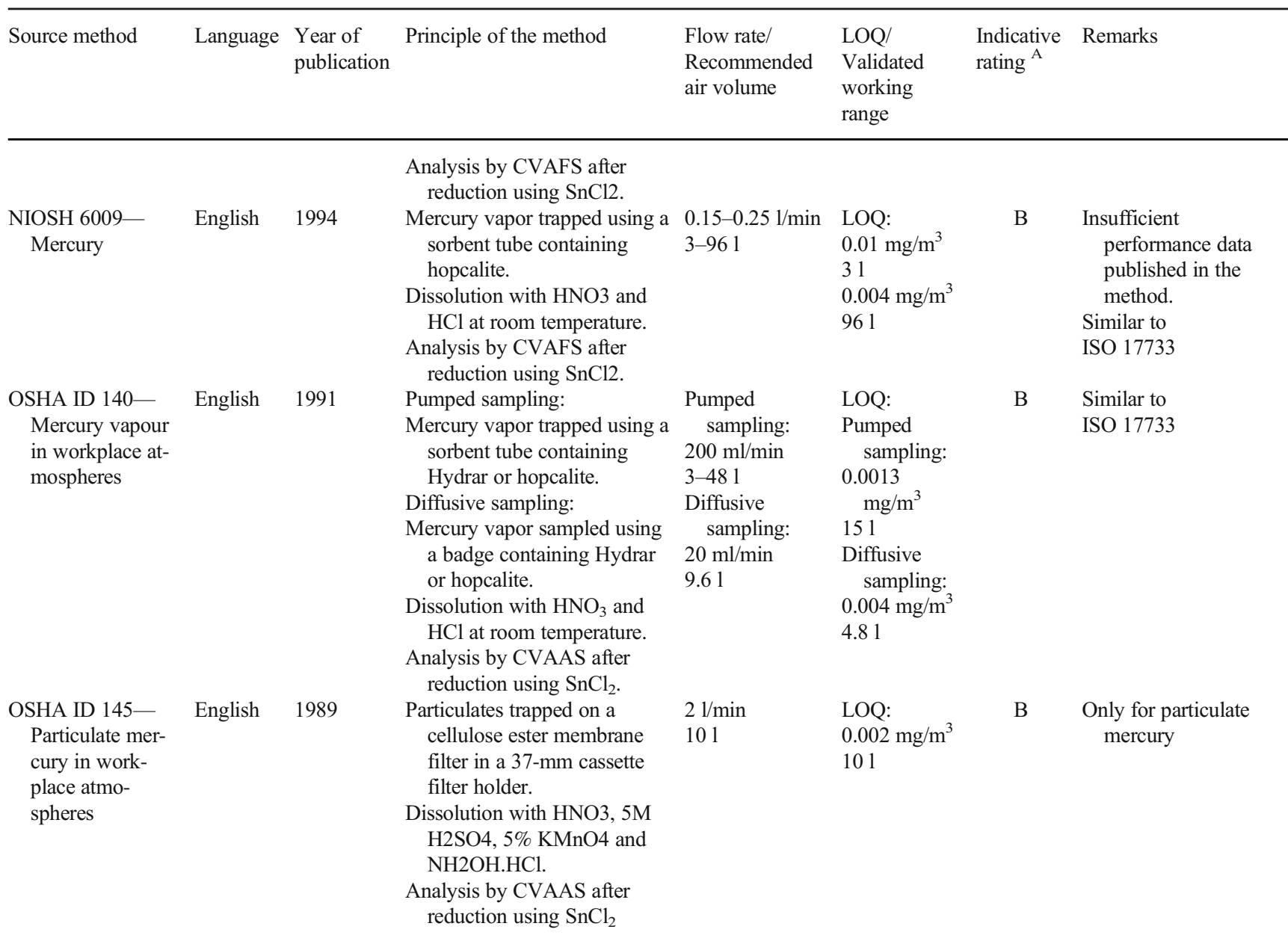

A The "indicative rating" heading is based on the requirements of EN 482 and three categories are defined: category A, if the method meets all of or the most of the major requirements of EN 482; category B, if there are incomplete validation data, but the method has the potential to meet the EN 482 requirements (normally only " $\mathrm{A}$ " and "B" methods are included in the list)

carried by an ultra-pure Ar flow to the "analytical trap" (i.e., the second trap along the sampling line); here $\mathrm{Hg}$ is desorbed for the second time, transported to the detector cell by the Ar flow, and determined by CVAFS (Fig. 2A).

Later, CEN developed a reference method (EN 15852:2010 — “Ambient air quality — Standard method for the determination of total gaseous mercury"), implemented by the Italian legislation with the Legislative Decree n. 250/ 2012. This protocol, defined as specific for TGM, outlines two sampling and analysis methods, reported as equivalent: the first one, "manual method" in the following, is based on the principle of gold amalgamation and the subsequent analysis by cold vapor atomic absorption spectrometry (CVAAS) or by CVAFS; the second one, "automatic method" in the following, is based on the "direct and continuous measurements of GEM by atomic absorption spectrometry (AAS) coupled with Zeeman background correction (Fig. 2).

The manual method is substantially similar to the method reported by Legislative Decree n. 155/2010, with the only exception that the analysis can be performed alternatively with CVAAS or CVAFS.

The automatic method is based on the Zeeman background correction, i.e., the differential Zeeman atomic-absorption spectrometry using a high-frequency modulation of light polarization (ZAAS-HFM). This process consists in the application of a permanent magnetic field to a radiation source (a $\mathrm{Hg}$ lamp), so that the resonance line of $\mathrm{Hg}(\lambda=254 \mathrm{~nm})$ is separated into three polarized components $\left(\pi, \sigma+\right.$, and $\left.\sigma^{-}\right)$, with the photo detector that records only the radiation of the $\sigma$ components (Fig. 2B). The Zeeman effect allows to avoid the $\mathrm{Hg}$ pre-concentration through gold amalgam or other type of adsorbent material, avoiding the interferences due to airborne PM or other contaminants that can be in the atmosphere. The use of automatic Hg analyzers using Zeeman correction (i.e., those of the Lumex ${ }^{\circledR}$ series) has exponentially increased in the last 20 years (Fig. 3), both for outdoor (i.e., Vaselli et al. 2013; Barago et al. 2020; Rimondi et al. 2020) and indoor surveys (Webber et al. 2011; Marcotte et al. 2017; Cabassi 
A)

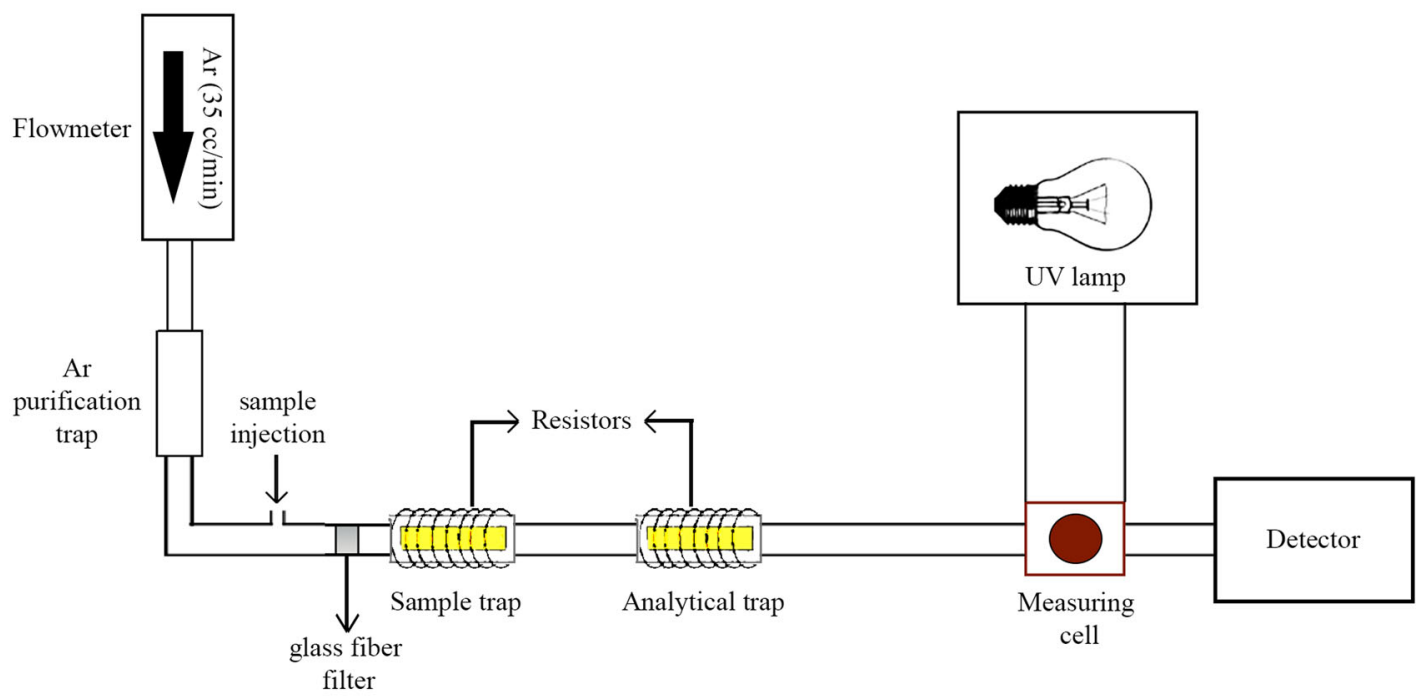

B)

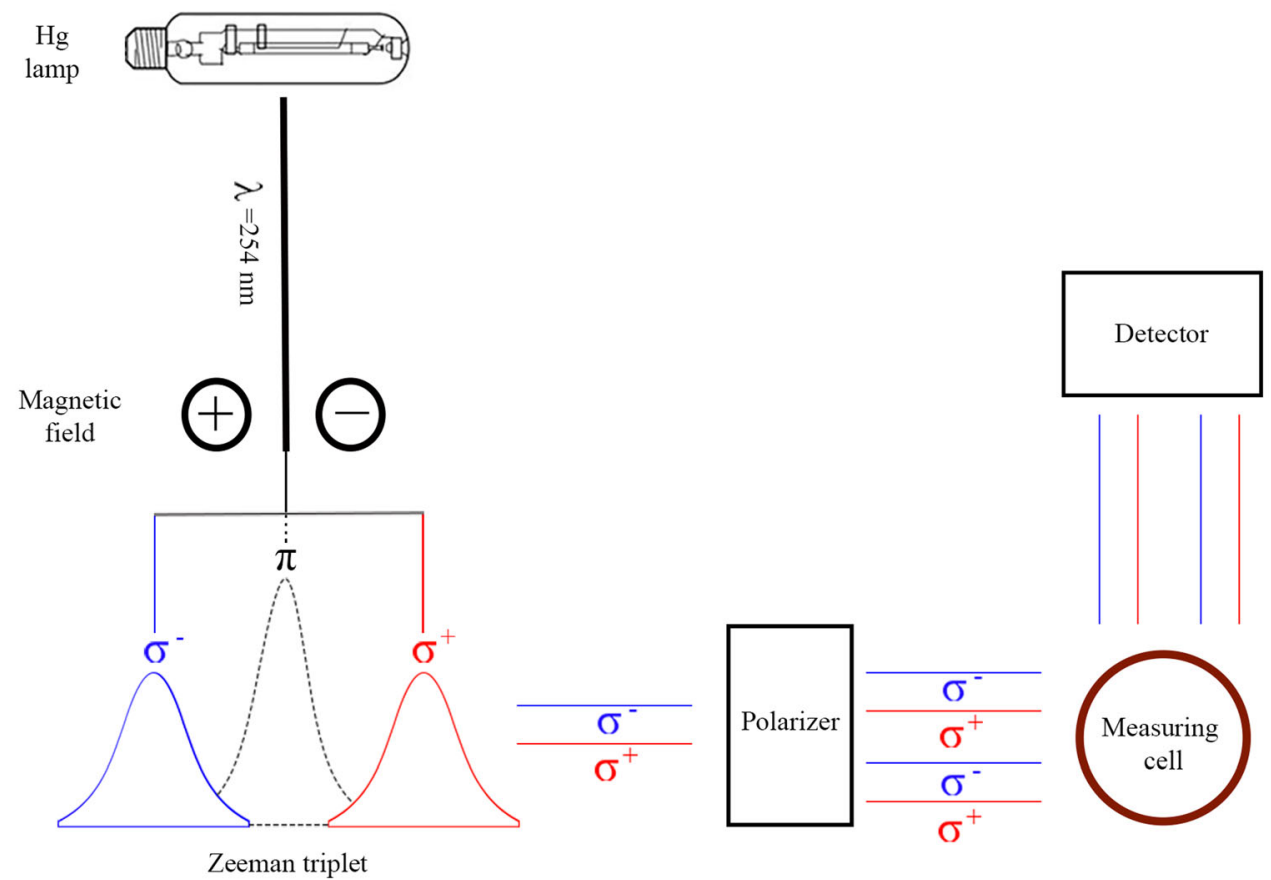

Fig. 2 The two reference method proposed by EN 15852:2010 for the determination of total gaseous mercury in outdoor environment

et al. 2020). These instruments are considered to be specific for quantifying exclusively $\mathrm{Hg}$ vapors (i.e., GEM) (Kim et al. 2006; Wang et al. 2007; Yang et al. 2009). This assumption is probably linked to (i) the abundance of $\mathrm{Hg}^{0}$ with respect to other $\mathrm{Hg}$ species in most of the environments and (ii) the literature studies where the parallel use of manual and automatic methods reported higher $\mathrm{Hg}$ level in the manual one (Kim et al. 2006; Witt et al. 2008), suggesting it may entrap even some RGM.

Moreover, both manual and automatic methods contemplate the use of a polytetrafluoroethylene filter with $0.2 \mu \mathrm{m}$ pores to remove the PM from the sampled air.

\section{The indoor environment}

As mentioned in Paragraph 3.2, the Italian legislation does not report a specific methodology to be applied in case of $\mathrm{Hg}$ indoor pollution and, in particular, in the workplace atmosphere, but we could refer to the procedures reported by the GESTIS Database (GESTIS 2015). Here, a particular importance for $\mathrm{Hg}$ sampling and analysis is attributed to the ISO 17733:2015, as the other methods listed in the database (i.e., NIOSH n. 6009 or OSHA ID-140 and OSHA ID-145) are assimilated to this one. The ISO 17733:2015 describes a procedure aimed at quantifying both gaseous Hg-compounds 


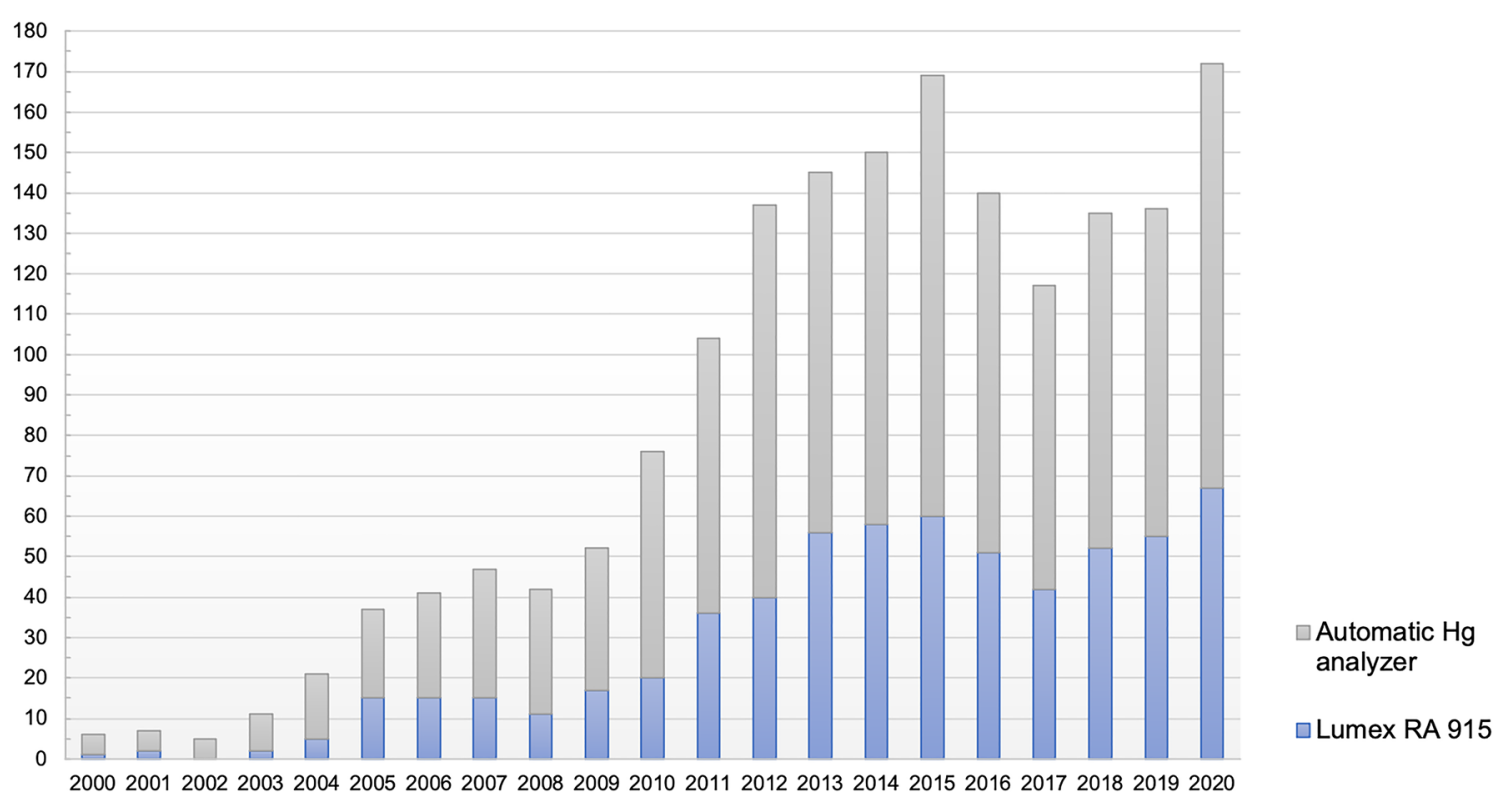

Fig. 3 Number of studies reported in scientific publications by Google Scholar that have used automatic methods for airborne Hg compounds quantification in the last 20 years. The Lumex RA 915 is the portable atomic absorption spectrometer of the Lumex ${ }^{\circledR}$ series

(named "mercury vapor") and/or "particulate inorganic mercury compounds", with their sum defined as total inorganic $\mathrm{Hg}$. The gaseous Hg compounds are sampled (i) passively, by diffusion on a badge containing a sorbent material, or (ii) actively, by pumping a known volume of air through a small tube (trap) containing the sorbent (Fig. 4). In the second case, the particulate inorganic Hg-compounds are collected through the use of a quartz fiber filter with a collection efficiency of not less than $99.5 \%$ for particles with a $0.3-\mu \mathrm{m}$ diffusion diameter, and subsequent analyzed by acid digestion techniques. Both methods are carried out by applying the sampling mean directly on the worker, as close as possible to the respiratory tract ("personal sampler"), or by placing the sampler in the closest proximity to the subject ("static sampler").
For the static sampler a pump connected the trap containing the sorbent (active sampling) is used. The different sampling methods (passive or active) are used depending on the specific application, i.e., absence/presence of particulate Hg-compounds. In passive sampling, the possibility to quantify PBM is indeed excluded.

The sorbent of the trap reported by the protocol, originally called Hydrar, is currently commercialized as Anasorb C 300. Hydrar is a granular preparation of hopcalite (a mixture of $\mathrm{Cu}$ and Mn oxides) deposited on a ceramic substrate; the specificity and irreversible affinity of hopcalite for $\mathrm{Hg}$ ( $\mathrm{Hg}$ vapors) has been shown by Rathje et al. (1974; Rathje and Marcero 1976). Other types of sorbent could be used in principle by the law, after certification of the equivalent performance.
Fig. 4 The devices reported by the ISO 17733:2015 for passive (A, the diffusive badge) or active sampling (B, the trap)
A)

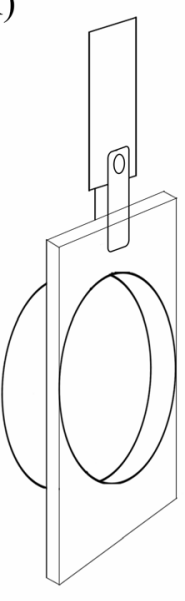

Sampler case

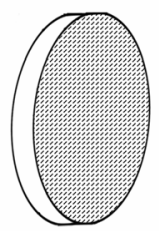

Sorbent disc
B)

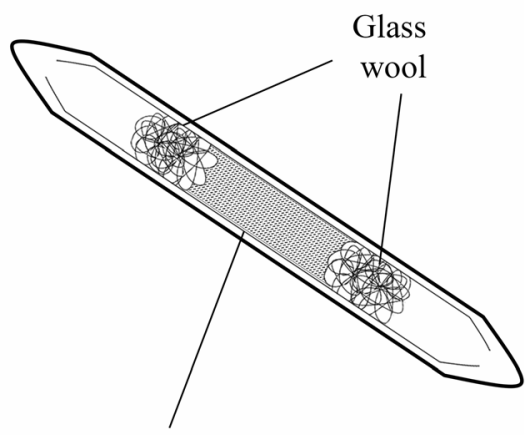

Sorbent 
After the sampling, the sorbent and/or the filter (according to the method used) are digested with a solution of $\mathrm{HNO}_{3}$ and $\mathrm{HCl}(1: 1) . \mathrm{Hg}$ is then measured by CVAAS or CVAFS after proper reduction of $\mathrm{Hg}^{2+}$ in solutions to $\mathrm{Hg}^{0}$ with $\mathrm{SnCl}_{2}$.

Among the ISO protocols developed to evaluate $\mathrm{Hg}$ pollution in workplace air, the International Organization for Standards (ISO) 205522007 is instead used for short-term sampling $(<15 \mathrm{~min})$ and is based on the principle of amalgam with $\mathrm{Au}$ and subsequent analysis by CVAAS or CVAFS. However, this protocol is not included in the list recommended by the GESTIS database and therefore has not a normative validity in the Italian country.

As previously written, the GESTIS database also reports other specific protocols for quantifying $\mathrm{Hg}$ in workplaces (Table 1). Among these, we list the methods developed by two US government agencies as NIOSH and OSHA.

The NIOSH n. 6009 (NIOSH 1994a, b) is a specific method developed for the sampling and analysis of $\mathrm{Hg}$ through the use of traps containing hopcalite as adsorbent material, similarly to what seen in the International Organization for Standards (ISO) 17733 2005. The NIOSH n. 6009 is specifically developed for GEM quantification, although it reports that a prefilter can be used if the particulate $\mathrm{Hg}$ compounds are to be quantified. However, the pore size or filter material is not specified.

The methods developed by OSHA to assess the Hg concentration in workplace air are instead two: the OSHA ID-140 is a specific method developed to quantify GEM, while the OSHA ID-145 provides a protocol to estimate exclusively PBM.

The OSHA ID-140 (OSHA 1991) reports the same method of the ISO 17733:2015 described above (active or passive sampling and Hydrar/hopcalite as sorbent). If particulate $\mathrm{Hg}$ compounds are expected to be in the workplace air, the protocol specifically reports the need to carry out the active sampling method, where a mixed-cellulose ester filter with $0.8 \mu \mathrm{m}$ pores is employed to exclude PBM from the analysis. This type of filter is the same of the OSHA ID-145 method (OSHA 1989), located before the suction pump (active sampling) and completely dissolved by a $\mathrm{HNO}_{3}$ and $\mathrm{H}_{2} \mathrm{SO}_{4}$ (1:1) solution, plus addition of $\mathrm{KMnO}_{4}$ to favor oxidation of the $\mathrm{Hg}$ compounds. The analysis is then performed through CVAAS as already outlined for 15773:2015.

\section{Discussion}

The problem of airborne Hg-compounds pollution has assumed increasing importance over the years, as highlighted by the numerous regulatory protocols drawn up with the aim to define specific methodologies to quantify $\mathrm{Hg}$ concentration in the atmosphere. Despite this evidence, these methods show evident problems, strongly linked to the definition of the $\mathrm{Hg}$ species being studied and to the differences between the protocols adopted by environmental or workplace legislation.

The different airborne Hg-compounds (GEM, RGM, PBM) are only operationally distinct on the basis of the sampling and analytical methodologies. The problem of the $\mathrm{Hg}$ contamination is therefore both methodological and legislative; the $\mathrm{Hg}$ species quantified are closely linked to the protocol imposed or recommended by the legislation. As a consequence, the sampling protocol and/or the instrumentation for analysis will affect the $\mathrm{Hg}$ species under investigation.

The European directives transposed by the Italian outdoor legislation always refer to the quantification of TGM, including in this definition all the atmospheric gaseous $\mathrm{Hg}$ forms. Despite this definition, the two methods reported in the EN 15852:2010 devoted to $\mathrm{Hg}$ quantification are quite different, especially because they quantify two different atmospheric $\mathrm{Hg}$ forms. The use of Au traps (the "manual method") is indeed not selective for $\mathrm{Hg}^{0}$ only, but rather for all the total gaseous $\mathrm{Hg}$ compounds (i.e., GEM + RGM = TGM) (Barghigiani et al. 1991; Gustin and Jaffe 2010; Pandey et al. 2011); conversely, the analysis based on ZAAS-HFM (the "automatic method") is likely specific for GEM, thanks to the high selectivity of the instruments that apply the Zeeman correction (Sholupov and Ganeyev 1995). The supposed equivalence of the two methods is probably based on the evidence that GEM is often the predominant species of TGM in outdoor environments and the possibility of choice may perhaps be linked to the background condition of the sampling site, or to the purpose for which the data will be used, i.e., environmental studies or workplace investigations. As a matter of fact, however, the studied analyte with automatic method does not strictly coincide with what is required by the Italian outdoor legislation. Nevertheless, the possibility of a real-time monitoring, as the case of the Lumex ${ }^{\circledR}$ portable analyzers, explains the increasing use of these instruments (Fig. 3) and the transposition of the automatic method as a standard analysis methodology; the reasons of this evidence are linked to the fast Hg determination, in addition to a high selectivity and a low detection limit, but above all to the ability to avoid further analytical steps.

On the other hand, the legislation for indoor environments (i.e., workplace) shows several obvious criticalities, in Italy as abroad. First of all, the close association between the sampling protocol/instrumentation for analysis and the studied $\mathrm{Hg}$ species finds the first problem in the Legislative Decree n. 81/ 2008 (the Italian legislation for health and safety in workplace). This text reports a "purely indicative" list of standardized methods, i.e., EN standards, that must be used for atmospheric chemical compounds quantification. Therefore, the wide variety of protocols and methods recommended by the legislation leaves a lot of arbitrariness of choice for the operator. Among these protocols, the standard ISO 17733:2015 (included in the GESTIS database) is considered the eligible method for atmospheric $\mathrm{Hg}$ compounds quantification, the 
one to which almost all the other methods reported in the GESTIS database refer.

In addition, the normative/methodological problems arise from the use of the word total which, as reported in the Italian indoor legislation, refers to the quantification of all the atmospheric Hg compounds and therefore also of the PBM. However, this $\mathrm{Hg}$ fraction is only partially defined by the method and instrumentation that must be used for its correct analysis. The quantification of PBM intrinsically needs the presence of a pre-filter on the air pumping device, which entraps the $\mathrm{Hg}$ species. Hence, an additional analysis is required, where the filter is digested and the $\mathrm{Hg}$ recovered summed to the $\mathrm{Hg}$ collected on the sorbent trap. For PBM is therefore fundamental to define the pore size of the filter devoted to particulate sampling. If a protocol/methodology does not specify this parameter, this will inevitably cause biased results among different studies, especially when studying environments where gaseous species accounted for most of the total $\mathrm{Hg}$, but the PBM fraction is still significant. This last statement may be true for outdoor environments (Pyta et al. 2009; $\mathrm{Fu}$ et al. 2015), but also for indoor atmosphere, both in workplaces (Liu et al. 2009) and in educational/recreational frameworks, like universities (Majewski et al. 2016) or museums (Marcotte et al. 2017).

The reference method for environmental analysis (UNI EN 15852 2010), reported by the Italian outdoor legislation and recommended to all Member States (EC directive 2015/1480/ EC 2015), does not require the analysis of PBM, and concordantly both the methods (manual and automatic) exclude it from the analysis by applying a polytetrafluoroethylene filter with $0.2 \mu \mathrm{m}$ pores. The situation is instead different for the workplace air legislation, where PBM should be quantified. The list of standardized methods reported in the Legislative Decree n. 81/2008 presents a standard (UNI EN 481) specifically aimed at the issue of airborne PM in workplace atmosphere; however, this method does not contain a precise sampling and analysis protocol, but rather only defines the size range through which it is possible to distinguish between inhalable (i.e., the PM fraction inhaled through nose and mouth), thoracic (the PM fraction penetrating beyond the larynx), and respirable (i.e., the PM fraction that can reach the unciliated airways) fractions (CEN 1993). However, there is no specification about the fractions to be analyzed for heavy metals analysis, comprising $\mathrm{Hg}$.

Among the methods suggested by the GESTIS database, the ISO 17733 provides two methods (active and passive) to quantify airborne $\mathrm{Hg}$, which differ for the $\mathrm{Hg}$ species being involved in the quantification. As elucidated by the method, the sampling and analysis of the PBM is indeed possible only employing the active sampling, where the presence of a filter to retain PM is dictated by the law. As a consequence, only the active method matches with the requirement of the Italian legislation.
However, as documented by GESTIS, the protocols for PBM sampling and analysis are not uniform. For example, the ISO 17733 requires the use of a filter with an efficiency of $99.5 \%$ for particles of $0.3 \mu \mathrm{m}$ diameter, while in the OSHA ID-145 a filter with $0.8 \mu \mathrm{m}$ pores is demanded. The dimensional difference between the two filters seems to be negligible for the estimation of PBM, being probably lost in the uncertainty of the measurement itself. Similarly, discrepancies are likely minor for the effect on health workers, since both filters' diameters refer to the dimensional range of PM 2.5 (i.e., particulates with an aerodynamic diameter $\leq 2.5 \mu \mathrm{m}$ ), excluding the ultra-fine particles (i.e., particulates with an aerodynamic diameter $\leq 0.1 \mu \mathrm{m}$ ) (Pandey et al. 2011; US EPA 2013). On the other hand, the size of the filter pores is not specified by the NIOSH n. 6009 method that reports the PBM quantification only as an additional analysis, leaving complete freedom in the choice of the filter to recover PM.

It is important to underline that these three methods are all included in the GESTIS database and therefore are not imposed, but only recommended; the choice of the method is a decision that only concerns the operator. From this point of view, the selection is probably related to the condition in which the measurements are conducted and which are the most likely exposure routes for workers, and therefore the prevailing $\mathrm{Hg}$ form.

As a result of this study, we highlight that a full knowledge of the standard methods for airborne $\mathrm{Hg}$ analysis is deemed before appointing a $\mathrm{Hg}$ monitoring campaigns in a workplace environment. It is indeed evident that GESTIS methods are not equivalent for $\mathrm{Hg}$ quantification, and that the monitoring operator, employing different sampling techniques, indirectly operate a decision of the $\mathrm{Hg}$ forms to be quantified. The lack of a unified procedure can lead to biased results when different sampling protocols are applied.

\section{Conclusion}

The present report reviews the international and Italian normative framework on the Hg pollution in outdoor and indoor environments. Moreover, the methodology approach is deeply examined. Furthermore, inconsistencies between the Hg species to be monitored by the law and the analytical approach to be followed are stressed out.

Undoubtedly, in recent years, the regulatory, and therefore also the methodological framework, has undergone major changes that have led to an increasingly specific analysis. According to the present study, it is of primary importance to firstly identify the $\mathrm{Hg}$ species that have to be analyzed by the law. The choice of a specific sampling and analytical methods and/or instruments for $\mathrm{Hg}$ analysis is subordinate to the Hg species to be investigated. This problem especially relates to the regulatory framework that, regarding the 
chemical pollution in workplace atmosphere, leaves considerable freedom in choosing the methodology to be used. The legislative problem also arises from the definition of the study analyte, which often does not coincide with the operational definition and therefore it does not correspond with the instrument or method recommended by the reference legislation; this is the case for both environmental and workplace legislation.

Authors' contributions Conceptualization: Valentina Rimondi, Pilario Costagliola. Literature search: Francesco Ciani. Writing - original draft preparation: Francesco Ciani. Writing - review and editing: Valentina Rimondi, Pilario Costagliola. All authors read and approved the final manuscript.

Funding Open access funding provided by Università degli Studi di Firenze within the CRUI-CARE Agreement.

Declarations The authors did not receive support from any organization for the submitted work

The authors have no conflicts of interest to declare that are relevant to the content of this article

All data used in this work can be freely downloaded or purchased from their online resources.

Open Access This article is licensed under a Creative Commons Attribution 4.0 International License, which permits use, sharing, adaptation, distribution and reproduction in any medium or format, as long as you give appropriate credit to the original author(s) and the source, provide a link to the Creative Commons licence, and indicate if changes were made. The images or other third party material in this article are included in the article's Creative Commons licence, unless indicated otherwise in a credit line to the material. If material is not included in the article's Creative Commons licence and your intended use is not permitted by statutory regulation or exceeds the permitted use, you will need to obtain permission directly from the copyright holder. To view a copy of this licence, visit http://creativecommons.org/licenses/by/4.0/.

\section{References}

ACGIH® (2020) Threshold limit values for chemical substances in the work environment. Adopted by ACGIH ${ }^{\circledR}$ with Intended Changes. http://www.acgih.org/.

AIHA (2002) The AIHA Emergency Response Planning Guidelines and Workplace Environmental Exposure Level Guidelines Handbook. AIHA Press. Fairfax (VA).

ATSDR (1999) Toxicological profile for mercury. Public Health Service, U.S. Department of Health and Human Services. Atlanta (GA)

Bank MS (2012) Mercury in the environment: pattern and process. Berkeley: University of California Press.

Barago N, Floreani F, Acquavita A, Esbrí JM, Covelli S, Higueras P (2020) Spatial and temporal trends of gaseous elemental mercury over a highly impacted coastal environment (Northern Adriatic, Italy). Atmosphere 11(9):935. https://doi.org/10.3390/ atmos11090935

Barghigiani C, Ristori T, Cortopassi M (1991) Air mercury measurement and interference of atmospheric contaminants with gold traps.
Environ Technol 12(10):935-941. https://doi.org/10.1080/ 09593339109385089

Cabassi J, Rimondi V, Yeqing Z, Vacca A, Vaselli O, Buccianti A, Costagliola P (2020) 100 years of high GEM concentration in the Central Italian Herbarium and Tropical Herbarium Studies Centre (Florence, Italy). J Environ Sci 87:377-388. https://doi.org/10.1016/ j.jes.2019.07.007

CEN (1993) Workplace atmospheres-size fraction definitions for measurement of airborne particles. CEN, British Standards Institute. Report No. BS EN 481:1993. London (UK)

EC directive 2004/107/EC (2004) Directive 2004/107/EC of the European Parliament and of the Council of 15 December 2004 relating to arsenic, cadmium, mercury, nickel and polycyclic aromatic hydrocarbons in ambient air. Off J Eur Union 23:3-16 http://data. europa.eu/eli/dir/2004/107/oj

EC directive 2008/50/EC (2008) Directive 2008/50/EC on ambient air and cleaner air for Europe. Off J Eur Union 151:1-44 http://data. europa.eu/eli/dir/2008/50/oj

EC directive 2015/1480/EC (2015) Commission Directive (EU) 2015/ 1480 of 28 August 2015 amending several annexes to Directives 2004/107/EC and 2008/50/EC of the European Parliament and of the Council laying down the rules concerning reference methods, data validation and location of sampling points for the assessment of ambient air quality. Off J Eur Union 226:4-11 http://data.europa.eu/ eli/dir/2015/1480/oj

Edner H, Faris GW, Sunesson A, Svanberg S (1989) Atmospheric atomic mercury monitoring using differential absorption LIDAR technique. Appl Opt 28:921-930. https://doi.org/10.1364/AO.28.000921

Fisher JF, World Health Organization (2003) Elemental mercury and inorganic mercury compounds: human health aspects. World Health Organization. https://apps.who.int/iris/handle/10665/42607

Fitzgerald WF, Engstrom DR, Lamborg CH, Tseng C, Balcom PH, Hammerschmidt CR (2005) Modern and historic atmospheric mercury fluxes in northern Alaska: global sources and arctic depletion. Environ Sci Technol 2:557-568. https://doi.org/10.1021/es049128x

Fu XW, Feng X, Shang LH, Wang SF, Zhang H (2012) Two years of measurements of atmospheric total gaseous mercury (TGM) at a remote site in Mt. Changbai area, Northeastern China. Atmos Chem Phys 12:4215-4226. https://doi.org/10.5194/acp-12-42152012

Fu XW, Zhang H, Yu B, Wang X, Lin CJ, Feng XB (2015) Observations of atmospheric mercury in China: a critical review. Atmos Chem Phys 15(16):9455-9476. https://doi.org/10.5194/acp-15-9455-2015

Gazzetta Ufficiale n. 213 (2007) Attuazione della direttiva 2004/107/CE concernente l'arsenico, il cadmio, il mercurio, il nichel e gli idrocarburi policiclici aromatici nell'aria ambiente. D.Lgs. n. 152. 13/09/2007.

Gazzetta Ufficiale n. 101 (2008) Attuazione dell'articolo 1 della legge 3 agosto 2007, n. 123 , in materia di tutela della salute e della sicurezza nei luoghi di lavoro. D.Lgs. n. 81. 09/04/2008.

Gazzetta Ufficiale n. 216 (2010) Attuazione della direttiva 2008/50/CE relativa alla qualità dell'aria ambiente e per un'aria più pulita in Europa. D.Lgs. n. 155. 13/08/2010.

Gazzetta Ufficiale n. 218 (2012) Allegato XXXVIII: valori limite di esposizione professionale, mercurio e composti inorganici divalenti del mercurio compresi ossido mercurico e cloruro di mercurio (misurati come mercurio). D.M. n. 81. 06/08/2012.

Gazzetta Ufficiale n. 23 (2013) Modifiche ed integrazioni al decreto legislativo 13 agosto 2010, n. 155, recante attuazione della direttiva 2008/50/CE relativa alla qualita' dell'aria ambiente e per un'aria piu' pulita in Europa. D.Lgs. n. 250. 24/12/2012.

GESTIS (2015) GESTIS-database on hazardous substances: information system on hazardous substances of the German Social Accident Insurance. [accessed 2020 May 27] https://amcaw.ifa.dguv.de/ 
Gustin MS, Jaffe D (2010) Reducing the uncertainty in measurement and understanding of mercury in the atmosphere. Environ Sci Technol 44(7):2222-2227. https://doi.org/10.1021/es902736k

Gustin MS, Amos HM, Huang J, Miller MB, Heidecorn K (2015) Measuring and modeling mercury in the atmosphere: a critical review. Atmos Chem Phys 15:5697-5713. https://doi.org/10.5194/ acp-15-5697-2015

Hong YS, Kim YM, Lee KE (2012) Methylmercury exposure and health effects. J Prev Med Public Health 45(6):353-363. https://doi.org/10. 3961/jpmph.2012.45.6.353

International Organization for Standards (ISO) 17733 (2005) Workplace air - determination of mercury and inorganic mercury compounds Method by cold vapour atomic absorption spectrometry or atomic fluorescence spectrometry. International Organization for Standardization. Geneva $(\mathrm{CH})$

International Organization for Standards (ISO) 20552 (2007) Workplace air - determination of mercury vapour - Method using goldamalgam collection and analysis by atomic absorption spectrometry or atomic fluorescence spectrometry. International Organization for Standardization. Geneva $(\mathrm{CH})$

Kim KH, Mishra VK, Hong S (2006) The rapid and continuous monitoring of gaseous elemental mercury (GEM) behavior in ambient air. Atmos Environ 40(18):3281-3293. https://doi.org/10.1016/j. atmosenv.2006.01.046

Kim KH, Kabir E, Jahan SA (2016) A review on the distribution of Hg in the environment and its human health impacts. J Hazard Mater 306: 376-385. https://doi.org/10.1016/j.jhazmat.2015.11.031

Kurt-Karakus PB (2012) Determination of heavy metals in indoor dust from Istanbul, Turkey: estimation of the health risk. Environ Int 50: 47-55. https://doi.org/10.1016/j.envint.2012.09.011

Landis MS, Stevens RK, Schaedlich F, Prestbo EM (2002) Development and characterization of an annular denuder methodology for the measurement of divalent inorganic reactive mercury in the ambient air. Environ Sci Technol 36:3000-3009. https://doi.org/10.1021/ es015887t

Liu Y, Zhan Z, Du F, Kong S, Liu Y (2009) Indoor air concentrations of mercury species in incineration plants for municipal solid waste (MSW) and hospital waste (HW). Chemosphere 75(2):266-271. https://doi.org/10.1016/j.chemosphere.2008.11.079

Lynam MM, Keeler GJ (2002) Comparison of methods for particulate phase mercury analysis: sampling and analysis. Anal Bioanal Chem 374(6):1009-1014. https://doi.org/10.1007/s00216-002-1584-4

Majewski G, Kociszewska K, Rogula-Kozłowska W, Pyta H, RogulaKopiec P, Mucha W, Pastuszka JS (2016) Submicron particlebound mercury in university teaching rooms: a summer study from two Polish cities. Atmosphere 7(9):117. https://doi.org/10.3390/ atmos 7090117

Marcotte S, Estel L, Minchin S, Leboucher S, Le Meur S (2017) Monitoring of lead, arsenic and mercury in the indoor air and settled dust in the Natural History Museum of Rouen (France). Atm Pollut Res 8(3):483-489. https://doi.org/10.1016/j.apr.2016.12.002

Morrow PE, Gibb FR, Johnson L (1964) Clearance of insoluble dust from the lower respiratory tract. Health Phys 10(8):543-555

Munthe J, Wängberg I, Pirrone N, Iverfeldt Å, Ferrara R, Ebinghaus R, Feng X, Gardfeldt K, Keeler G, Lanzillotta E, Lindberg SE, Lu J, Mamane Y, Prestbo E, Schmolke S, Schroeder WH, Sommar J, Sprovieri F, Stevens RK, Stratton W, Tencel G, Urba A (2001) Intercomparison of methods for sampling and analysis of atmospheric mercury species. Atmos Environ 35(17):3007-3017. https://doi.org/10.1016/S1352-2310(01)00104-2

NIOSH (1981) Occupational Health Guidelines for Chemical Hazards. U.S. Department of Health and Human Services (DHHS). U.S. Department of Labor. Publication Number 81-123.

NIOSH (1994a) Documentation for immediately dangerous to life or health concentrations (IDLHS). US Department of Health and Human Service. Publication Number PB-94-195047.
NIOSH (1994b) Method 6009, Mercury. NIOSH Manual of Analytical Methods. US Department of Health and Human Service. Publication Number 94-113.

Obrist D, Johnson DW, Lindeberg SE (2009) Mercury concentrations and pools in four Sierra Nevada forest sites, and relationship to organic carbon and nitrogen. Biogeosci Discuss 6:1777-1809

OSHA (1989) Particulate Mercury in Workplace Atmospheres. Method ID 145. OSHA Technical Center, Division of Industrial Hygiene Chemistry Division. Salt Lake City (UT)

OSHA (1991) Mercury Vapor in Workplace Atmospheres. Method ID 140. OSHA Technical Center, Division of Physical Measurements and Inorganic Analyses. Salt Lake City (UT)

OSHA (1998) Occupational safety and health standards, toxic and hazardous substances. Code of Federal Regulations. 29 CFR 1910.1000. [accessed 2020 May 24] https://www.osha.gov/ lawsregs/regulations/standardnumber/1910/1910.1000

Pandey SK, Kim KH, Brown RJ (2011) Measurement techniques for mercury species in ambient air. Trends Anal Chem 30(6):899917. https://doi.org/10.1016/j.trac.2011.01.017

Park JD, Zheng W (2012) Human exposure and health effects of inorganic and elemental mercury. J Preven Med Pub Health 45(6):344 352. https://doi.org/10.3961/jpmph.2012.45.6.344

Pyta H, Rosik-Dulewska C, Czaplicka M (2009) Speciation of ambient mercury in the Upper Silesia Region, Poland. Water Air Soil Pollut 197(1-4):233-240. https://doi.org/10.1007/s11270-008-9806-9

Rathje AO, Marcero DH (1976) Improved hopcalite procedure for the determination of mercury vapor in air by flameless atomic absorption. Am Ind Hyg Assoc J 5:311-314. https://doi.org/10.1080/ 0002889768507460

Rathje AO, Marcero DH, Dattilo D (1974) Personal monitoring technique for mercury vapor in air and determination by flameless atomic absorption. Am Ind Hyg Assoc J 35:571-575. https://doi.org/10. 1080/0002889748507074

Rimondi V, Costagliola P, Benesperi R, Benvenuti M, Beutel MW, Buccianti A, Chiarantini L, Lattanzi P, Medas D, Parrini P (2020) Black pine (Pinus nigra) barks: A critical evaluation of some sampling and analysis parameters for mercury biomonitoring purposes. Ecol Indic 112:106110. https://doi.org/10.1016/j.ecolind.2020. 106110

Schroeder WH, Munthe J (1998) Atmospheric Mercury - An Overview. Atmos Environ 29:809-822. https://doi.org/10.1016/S13522310(97)00293-8

Settimo G, Manigrasso M, Avino P (2020) Indoor air quality: a focus on the European Legislation and State-of-the-Art Research in Italy. Atmosphere 11(4):370. https://doi.org/10.3390/atmos11040370

Sholupov SE, Ganeyev AA (1995) Zeeman absorption spectrometry using high frequency modulated light polarization. Spectrochim Acta B 50:1227-1238. https://doi.org/10.1016/0584-8547(95) 01316-7

UNI EN 15852 (2010) Ambient air quality - standard method for the determination of total gaseous mercury.

US EPA (2013) Particulate Matter (PM). US EPA Air \& Radiation. www.epa.gov/pm/index.html.

Vaselli O, Higueras P, Nisi B, Esbrí JM, Cabassi J, Martínez-Coronado A, Tassi F, Rappuoli D (2013) Distribution of gaseous Hg in the Mercury mining district of Mt. Amiata (Central Italy): A geochemical survey prior the reclamation project. Environ Res 125:179-187. https://doi.org/10.1016/j.envres.2012.12.010

Wang ZW, Chen ZS, Ning D, Zhang XS (2007) Gaseous elemental mercury concentration in atmosphere at urban and remote sites in China. J Environ Sci 19(2):176-180. https://doi.org/10.1016/ S1001-0742(07)60028-X

Webber WB, Ernest LJ, Vangapandu S (2011) Mercury exposures in university herbarium collections. J Chem Health Saf 18(2):11-14. https://doi.org/10.1021/acs.chas.8b18206 
WHO (2003) Elemental mercury and inorganic mercury compounds: human health aspects. Concise International Chemical Assessment Document 50. Geneva $(\mathrm{CH})$

Witt MLI, Mather TA, Pyle DM, Aiuppa A, Bagnato E, Tsanev VI (2008) Mercury and halogen emissions from Masaya and Telica volcanoes, Nicaragua. J Geophys Res 113:B6. https://doi.org/10. 1029/2007JB005401
Yang Y, Chen H, Wang D (2009) Spatial and temporal distribution of gaseous elemental mercury in Chongqing, China. Environ Monit Assess 156:1-4. https://doi.org/10.1007/s10661-008-0499-8

Publisher's note Springer Nature remains neutral with regard to jurisdictional claims in published maps and institutional affiliations. 